\title{
Evaluation Tool for Teachers' Training Projects of Environmental Education
}

\author{
Maria Kalathaki ${ }^{1, *}$ \\ ${ }^{1}$ School Advisor for Science Teachers of Secondary Education, Regional Educational \\ Directorates of Crete, Heraklion, Crete, Greece \\ *Correspondence: School Advisor for Science Teachers of Secondary Education, Regional \\ Educational Directorates of Crete, Knossos Avenue 6, Postal Code 71306, Heraklion, Crete, \\ Greece. Tel: 30-281-075-1469, E-mail: kalathakimaria.edu@gmail.com
}

Received: August 8, 2014

doi:10.5296/ije.v7i1.6927
Accepted: December 26, 2014 Published: January 16, 2015

URL: http://dx.doi.org/10.5296/ije.v7i1.6927

\begin{abstract}
In the field of the implementation of innovative interdisciplinary projects such as the Environmental Education Projects and Adult Education, last years' great effort was to create criteria-quality indicators. The criteria of relevance between Environmental Education Projects and Adult Education prepared for the purposes of this research are quantified expression of the contact points of Adult Education and Environmental Education. They referred to the research questions, such as study of the existing situation and assessment of significant data for designing a training project, determination of the scope and objectives of the educational project, description of the content project, selection of pedagogical and teaching methods, techniques and educational resources, determination of requirements for the implementation of the project, prediction of mechanisms for dissemination of the project results.
\end{abstract}

Keywords: Environmental Education, Teachers' Training, Evaluation Tool, Adult Education 


\section{Introduction}

According to the Council of the European Commission, the motivation, skills and competences of teachers, trainers, other teaching staff and guidance and welfare services, as well as the quality of school leadership, are key factors in achieving high quality learning outcomes (CEC, 2007). Eight key competences are identified, which are communication in the mother tongue; communication in foreign languages; basic competences in maths, science and technology; digital competence; learning to learn; Interpersonal, intercultural and social competences, and civic competence; entrepreneurship cultural expression. These are underpinned by basic skills, and include 'horizontal components' such as critical thinking, creativity, the European dimension, and active citizenship. Taken together, and into account in a training program design, they contribute to achieve personal fulfilment, active participation and improvement of person's employability. The changes are global. Globalisation is a multiple layered phenomenon that has economic, political, social and cultural dimensions.

In Greece, teaching and trainees' profession is not taught, in generally, but practiced empirically. The acquired teaching experience, as it does not fall within appropriate standards, has negative effect on teaching work because, unwittingly, it reproduces the teaching experience gained from the passed educational system that usually reflects the traditional one (Kokkos, 2008). Within the last years, the interest in the implementation of educational programs of Environmental Education (EE) has been widened, encouraged and supported by the educational authorities and the local government. Moreover, the need of transformation of the role of the school in modern society, by experiential way of learning in combination with the social demand for internal reform of schools and opening in the local community created the conditions for the promotion of EE in schools (UNESC, 2004).

The main axes of designing an AE project are determination of the target group, methods and techniques to be followed, the purpose and objectives of the project, the infrastructure of the project (costs, especially personnel undergoing training, educational material, sites), planning and the schedule of the project, the development of mechanisms for management, administration and coordination, project evaluation (Vergidis, 1999; Kapsalis \& Papastamatis, 2000). In the field of the implementation of innovative interdisciplinary projects such as the $\mathrm{EE}$ programs and $\mathrm{AE}$, the last years, great effort is being given to create criteria-quality indicators (Dimitropoulos, 1999; Hesselink et al, 2000; Wong \& Yeung, 2003; McKeown, 2011; EKDDA 2013). The criteria of relevance between EE programs and AE prepared for the purposes of this research are quantified expression of the contact points of EE and AE.

The Research Questions were: study of the existing situation and assessment of significant data for designing a training project, determination of the scope and objectives of the educational project, description of the project content, selection of pedagogical and teaching methods, techniques and educational resources, determination of requirements for the implementation of the project, prediction of mechanisms for dissemination of the project results. Each research question has sub-queries and evaluation criteria. 


\section{Methodology}

The purpose of this study was the construction of a tool for the evaluation of Greek Environmental Teachers' Training Projects (ETTPs). The tool can be used at the beginning of the project, immediately after the design, to assess whether it satisfies the principles, the objectives and the proposed methodology of the AE and the EE and at the end of the materialization of the project, before writing the final report, in order to assess if aims and goals were succeeded according to the European Union and UNESCO strategies, and to evaluate finally how effective the project was (output). Essentially, the research questions are also the objects of evaluation of the AE program because each project is a general object of evaluation. The particular factors that make it up are the special objects of the evaluation, as trainers, trainees, mounting, space etc (Bell J. (1997); Dimitropoulos, 1996). The criteria correspond to the dimensions of specific objects of the evaluation. The groups of criteria were established to satisfy the goals, the methodology and the expectations of the adult education and environmental education, ensuring that the areas of this investigation are not arbitrary choices. The developed literature review was done in Greek and foreign literature, in websites, books, journals, scientific conferences, circulars of the Greek Ministry of Education. The selection of the criteria was based on the principles of design, construction and implementation of adult education projects of Aegean University's guidelines for the school environmental projects, Pedagogical Institute researches, teachers' training project of the Metsovion National Technical University of Athens (MNTUoA, 2007), the objectives and methodology of environmental education, as expressed in the Tbilisi Conference (1977) and Thessaloniki (1997) (UNESC, 2004). Opinions of researchers related to the studied subject, associated conclusions and suggestions were investigated and taken into account (Vergidis, 1999; Sofoules, 2005; Kapsalis \& Papastamatis, 2000; Dimitropoulos, 1999; Zigouri., 2005; Flogaiti, 2006; Dimitriou, 2007; Kastani, 2005).

The various categories/axes and subjects were not defined beforehand, because in qualitative analysis, the classification system is adopted, developed and changed as advancing and evolving data analysis and information, resulting, in the coding of data, needs to be repeated from the beginning, and every time meanings and new categories are emerging. The perception and understanding of things always depend on a framework, conditions of the knowledge and experience are produced of the exchange between the relied frames and the perceptions (Cohen \& Manion, 1994; Iosifidis, 2003).

To serve the 6 Research Questions and 27 sub-queries, were prepared 93 evaluation criteria which constitutes the Content Analysis Tool (Tables I-VI). This methodological tool makes the measurement of an attribute possible, also the degree of fluctuation as appropriate, because it provides the possibility of reconciling the design of environmental projects with the $\mathrm{AE}$ project, in order to ensure their effectiveness in teachers training, acting as "quality indicator" (Frangoulis, 2006). 


\section{Results and Discussion}

The criteria that took into account the analysis of the research questions and sub-queries for the evaluation of an environmental teachers' training project are listed in Tables I-VI.

\subsection{Study of existing conditions and assessment of significant data for designing a training project}

Both initial and continuing education and training must renew itself to correspond to the demands of a knowledge-based and networked society (CEU, 2009). Especially for the assessment and evaluation of teachers training, European Commission has raised standards of teaching and teacher education through the Education and Training 2010 project ('ET2010') facilitating the exchange of information and experience between policymakers and helping teachers to develop their professional competences by funding their attendance at an in-service training course abroad (CEC, 2007; UNECE, 2005).

3.1.1 Awareness of the current situation and the educational policies followed. The AE programs are designed in order to respond to specific problems within wider policies. They comprise data collection for the existing situation, by focusing on particular issues, such as the broader policies that are or will be implemented by the national and supranational authorities in $\mathrm{EE}$ and $\mathrm{AE}$, the legal framework, the strategies and priorities of the educational and training institutions, the function of the bodies that belongs to the target population (ADA, 2013).

3.1.2 Components of the current situation. The components of the current situation, upon which are designed the educational and adult literacy projects, listed in Table I, analyse the policies, the strategies and the institutional context of the adult education, the demography by sex and age, the economic status (employment, unemployment, poverty, economic infrastructure development projects, expected economic developments), the social status (services, polices, conflicts and controversies, particular social groups and social exclusion), political developments and interventions, topical education level of the trainees, the network of formal and non-formal education, the educational facilities, instructors, etc. 
Table I. Evaluation Tool for Content Analysis: Criteria for the Evaluation of the Environmental Teachers' Training Projects regarding the Study of Existing Conditions and Assessment of Significant Data for Designing a Training Project

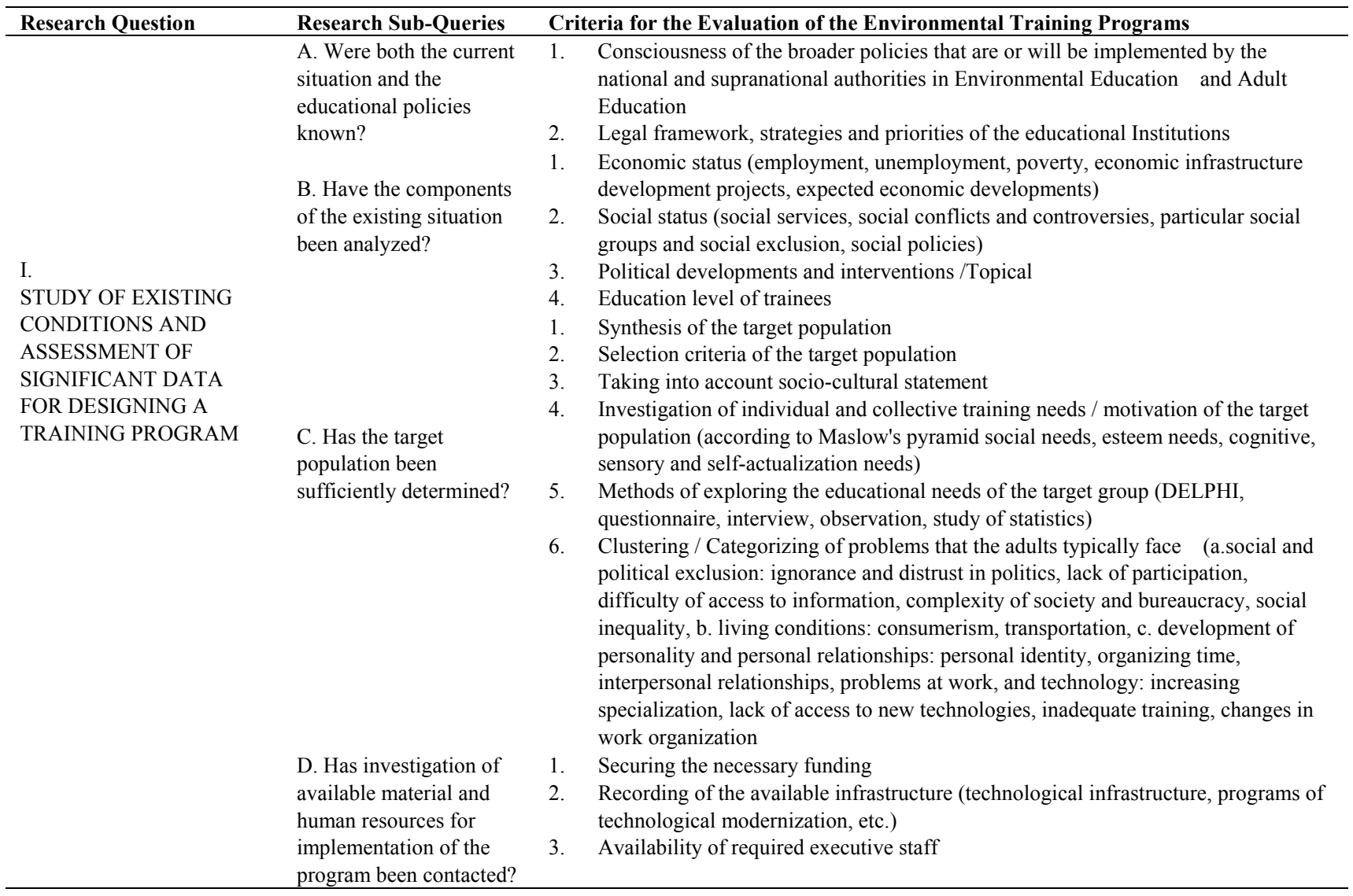

Table II. Evaluation Tool for Content Analysis: Criteria for the Evaluation of the Environmental Teachers' Training Projects regarding the Determination of the Purpose and Objectives of the Environmental Training Project

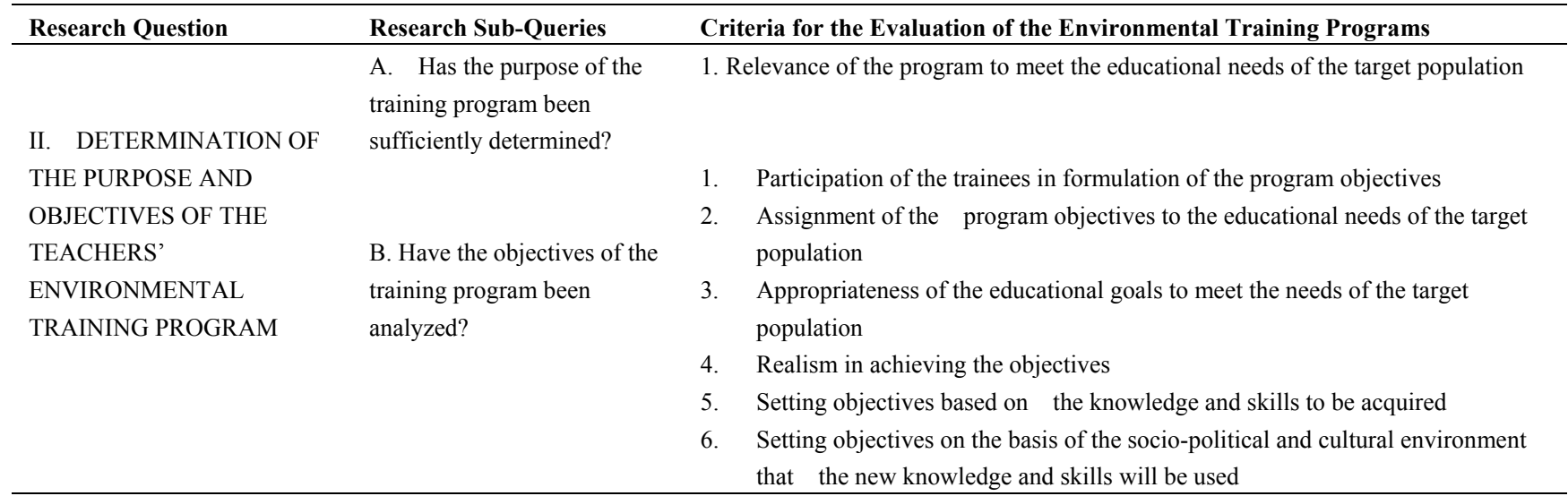


Table III. Evaluation Tool for Content Analysis: Criteria for the Evaluation of the Environmental Teachers' Training Projects regarding the Description of the Project Content

\begin{tabular}{|c|c|c|}
\hline Research Question & Research Sub-Queries & Criteria for the Evaluation of the Environmental Training Programs \\
\hline \multirow{9}{*}{$\begin{array}{l}\text { III. DESCRIPTION OF } \\
\text { THE CONTENT OF THE } \\
\text { PROGRAM }\end{array}$} & \multirow{4}{*}{$\begin{array}{l}\text { A. Is there an analysis of the } \\
\text { program content? }\end{array}$} & 1. Proper documentation / completeness of the content of the program \\
\hline & & 2. Analysis / Clarification / Clear description of the object of the program \\
\hline & & 3. Connection with everyday life \\
\hline & & 4. Adequacy to meet training needs and objectives \\
\hline & \multirow{5}{*}{$\begin{array}{l}\text { B. Is the program content } \\
\text { being structured? }\end{array}$} & 1. Classification of the program content (matter distribution into sections, separation \\
\hline & & of theoretical training and exercise \\
\hline & & $\begin{array}{l}\text { 2. Levels of the construction of the program content, by a. the knowledge of the } \\
\text { trainees, b. the level of skills/competencies development with the practical } \\
\text { exercise, c. the level of changing attitudes, values and behavior in order to } \\
\text { improve the communication capacity and collaborative ability of the trainees }\end{array}$ \\
\hline & & $\begin{array}{l}\text { 3. Temporal sequence and rhythm of the program (total duration, duration of the } \\
\text { theoretical training and practice) }\end{array}$ \\
\hline & & 4. Fullness and clarity of the program proposal \\
\hline
\end{tabular}

Table IV. Evaluation Tool for Content Analysis: Criteria for the Evaluation of the Environmental Teachers' Training Project regarding the Selection of Pedagogic and Teaching Methods, Techniques and Educational Resources

\begin{tabular}{|c|c|c|}
\hline Research Question & Research Sub-Queries & Criteria for the Evaluation of the Environmental Training Programs \\
\hline \multirow{20}{*}{$\begin{array}{l}\text { IV. SELECTION OF } \\
\text { PEDAGOGIC AND } \\
\text { TEACHING METHODS, } \\
\text { TECHNIQUES AND } \\
\text { EDUCATIONAL RESOURCES }\end{array}$} & & Trainers-centered philosophy \\
\hline & A. Supported the self-directed & Building on the experience of learners \\
\hline & & 4. Decision on the selection of learning methods \\
\hline & & Self-evaluation \\
\hline & $\begin{array}{l}\text { B. Are the issues approaching } \\
\text { inter/multi-disciplinary? }\end{array}$ & $\begin{array}{l}\text { 1. Interdisciplinary/multidisciplinary/holistic approach of the objects of the } \\
\text { program }\end{array}$ \\
\hline & \multirow{2}{*}{$\begin{array}{l}\text { C. Is the critical capacity of } \\
\text { trainees developed? }\end{array}$} & $\begin{array}{l}\text { 1. Awareness of the mechanisms of creation, termination and evaluation of a } \\
\text { problem }\end{array}$ \\
\hline & & 2. Learning how to learn/meta-cognition \\
\hline & \multirow{8}{*}{$\begin{array}{l}\text { D. Has the program innovative } \\
\text { elements at various levels? }\end{array}$} & 1. Exploiting diverse of learning environments, methods, activities \\
\hline & & 2. Topic selection \\
\hline & & of methods, etc) \\
\hline & & $\begin{array}{l}\text { 4. Techniques (i.e. lecture, roundtable seminar, working groups, peer } \\
\text { learning, etc) }\end{array}$ \\
\hline & & 5. Promoting intercultural education \\
\hline & & $\begin{array}{l}\text { 6. Developing partnerships with other programs, educational centers and } \\
\text { environmental networks }\end{array}$ \\
\hline & & $\begin{array}{l}\text { 7. Outdoor activities (visits, environmental pathways, field work, social } \\
\text { actions) }\end{array}$ \\
\hline & & $\begin{array}{l}\text { 8. Promotion of sustainability's components (caring } \\
\text { environment-solidarity-social justice etc) }\end{array}$ \\
\hline & & 1. Develop a sense of participation-awareness-alert in problem solving \\
\hline & & 2. Active involvement of participants in all phases of the decisions \\
\hline & & 5. Individualization of teaching by using of PCs, libraries etc. \\
\hline & & Undertake initiatives to address issues (self-motivated) \\
\hline & F.Has emphasis on analysis of & 1. Emergence of personal experiences \\
\hline
\end{tabular}




\begin{tabular}{|c|c|c|}
\hline $\begin{array}{l}\text { local/topical issues/of personal } \\
\text { interest of learners been given? }\end{array}$ & $\begin{array}{l}2 . \\
3 . \\
4 .\end{array}$ & $\begin{array}{l}\text { Engagement of the local community } \\
\text { Global dimension of local issues } \\
\text { Exploitation of the program results in a personal/local/national level }\end{array}$ \\
\hline $\begin{array}{l}\text { G. Are analyzed the needs of } \\
\text { evaluation? }\end{array}$ & $\begin{array}{l}1 . \\
2 .\end{array}$ & $\begin{array}{l}\text { Serving the purpose and objectives of the program } \\
\text { Serving the needs / expectations of the operator entrusted with } \\
\text { implementation of the program } \\
\text { Serving the needs / expectations of participants } \\
\text { Meet the requirements of entities and funding and of the evaluation } \\
\text { recipients (institutions, organizations, individuals) }\end{array}$ \\
\hline $\begin{array}{l}\text { H. Are they described the } \\
\text { evaluation objectives? (Not } \\
\text { necessarily coincide with the } \\
\text { objectives of the program) }\end{array}$ & $\begin{array}{l}1 . \\
2 . \\
3 . \\
4 . \\
5 .\end{array}$ & $\begin{array}{l}\text { Justification for the need to assess the objectives } \\
\text { Recipients of the conclusions of the evaluation } \\
\text { Build on the conclusions of the evaluation } \\
\text { Use of infrastructure } \\
\text { Efficiency of the trainers / human resources }\end{array}$ \\
\hline $\begin{array}{l}\text { I. Is chosen the type and the } \\
\text { model of evaluation? }\end{array}$ & $\begin{array}{l}2 . \\
3 .\end{array}$ & $\begin{array}{l}\text { Evaluation on the basis the objectives of the program for the determination } \\
\text { of their achievement } \\
\text { Independent evaluation of the program objectives } \\
\text { Use of initial, formative and final evaluation }\end{array}$ \\
\hline $\begin{array}{l}\text { IA. Set out a timetable and } \\
\text { budget for evaluation? }\end{array}$ & $\begin{array}{l}1 . \\
2 .\end{array}$ & $\begin{array}{l}\text { Investigation of the availability of actors to engage in the evaluation } \\
\text { Adaptive Control of the timing of the assessment with the time of } \\
\text { completion of the program }\end{array}$ \\
\hline
\end{tabular}

Table V. Evaluation Tool for Content Analysis: Criteria for the Evaluation of the Environmental Teachers' Training Projects regarding the Determination of Requirements for the Implementation of the Project

\begin{tabular}{|c|c|c|}
\hline Research Question & Research Sub-Queries & Criteria for the Evaluation of the Environmental Training Programs \\
\hline & & 1. Expenditure required to purchase additional equipment \\
\hline & A . Has the budget been & 2. Expenditure required for fees \\
\hline & prepared? & 3. Availability of Trainees \\
\hline & & 1. Adequacy, quality, usability \\
\hline & $\begin{array}{l}\text { B. Has the required space } \\
\text { been explored? }\end{array}$ & 2. Type of use and suitability \\
\hline V. & & 1. Available PCs \\
\hline DETERMINATION OF & C. Have the required & 2. Internet access \\
\hline REQUIREMENTS FOR THE & equipments been decided/ & Access to libraries \\
\hline IMPLEMENTATION OF THE & recorded? & 4. Adequacy, quality, usability \\
\hline \multirow[t]{8}{*}{ PROGRAM } & D. Has the necessary & 1. Qualified teaching staff (training, experience) \\
\hline & scientific/ administrative & 2. Utilization of external collaborators \\
\hline & support been ensured? & \\
\hline & E. Have the sources of & 1. Providing access to sources of knowledge \\
\hline & knowledge been listed? & 2. Availability of educational/scientific staff \\
\hline & & $\begin{array}{l}\text { 3. Previous Experience in designing and implementing educational } \\
\text { programs }\end{array}$ \\
\hline & F. Has the required duration & 1. \\
\hline & been estimated? & 2. Realism in the duration of the program \\
\hline
\end{tabular}


Table VI. Evaluation Tool for Content Analysis: Criteria for the Evaluation of the Environmental Teachers' Training Projects regarding the Prediction of Mechanisms for the Dissemination of Project Results

\begin{tabular}{|c|c|c|}
\hline Research Question & Research Sub-Queries & Criteria for the Evaluation of the Environmental Training Programs \\
\hline \multirow{4}{*}{$\begin{array}{l}\text { VI. PREDICTION OF } \\
\text { MECHANISMS FOR } \\
\text { DISSEMINATION OF } \\
\text { PROGRAM RESULTS }\end{array}$} & $\begin{array}{l}\text { A. Is there prediction for } \\
\text { feedback? }\end{array}$ & $\begin{array}{l}\text { 1. Organization of workshops, open discussions } \\
\text { 2. Production and distribution of material produced for the needs of the program } \\
\text { 3. Improvement of the program itself and any repetition by using the findings of } \\
\text { the evaluation }\end{array}$ \\
\hline & & 1. Provision of the mode for detection of the results \\
\hline & $\begin{array}{l}\text { B. Are the desired results } \\
\text { determined? }\end{array}$ & $\begin{array}{l}\text { 2. Satisfaction with the expectations of the target group } \\
\text { 3. Satisfaction of the proposals and choices of trainees } \\
\text { 4. Meet of social requirements }\end{array}$ \\
\hline & $\begin{array}{l}\text { C. Who are the ultimate } \\
\text { beneficiaries? }\end{array}$ & 1. Invitation to local agencies and those who related to the subject \\
\hline
\end{tabular}

3.1.3 Determination of the target population. The identification, recording and analysis of training needs of the applicants, with the investigation and analysis of the factors that contribute to the creation and maintenance of these needs, are primordial and key step in the design of the project, as they lay down the content, the methodology, the required and available resources, the evaluation, etc. The personal characteristics of adults that have been taken into account at a training project are about their goals, expectations, interests, motivations, attitudes, experiences, and personal needs. These are related to social-economic-cultural facts, individual and collective training needs of the target population. The criteria, related to the synthesis of the target population and to the socio-economic-cultural statement, evaluate if the investigation was developed on the individual and collective training needs and the motivations of the target population. According to the Maslow's pyramid, these are social needs, esteem needs, cognitive, sensory and self-actualization needs, by using methods of exploring the educational needs of the target group. Problems that the adults topically face, need to be clustered and categorized in a. social and political exclusion: ignorance and distrust in politics, lack of participation, difficulty of access to information, complexity of society and bureaucracy, social inequality, b. living conditions: consumerism, transportation, c. development of personality and personal relationships: personal identity, organizing time, interpersonal relationships, problems at work, and technology: increasing specialization, lack of access to new technologies, inadequate training, changes in work organization.

3.1.4 Investigation of available material and human resources for implementation of the project. Teachers of primary and secondary education who participated in training projects of the Peripheral Training Centres in some regions of Greece, described the profile of the successful trainer in environmental education projects as follows: he should be sensitized to the issues and problems of the young generation and the education and the environment, updated on the economic, technological, social and institutional structures, functions and developments of the issues and problems of the environment, trained in research practices and the evaluative processes of the EE projects, cultivated in terms of society, economy, technology and aesthetics, also sensitive to all messages deriving from the global and local 
social and cultural events (Skordoulis \& Sotirakou, 2005).

The criteria listed in Table 1, are securing the necessary funding, recording of the available infrastructure, as technological infrastructure, projects of technological modernization, etc, and availability of required executive staff.

\subsection{Determination of the purpose and objectives of the educational program}

One of the goals of ESD is to move university students from passive study to active implementation of sustainability. The metaphor often used related to this transformation is changing from 'talking the talk' to 'walking the talk'. The journey from talking to walking is a multi-step process rather than a single leap (Mackeown, 2011). Given the complexity of the demands placed upon teachers, the range of knowledge and skills that are required to master, and the need for them to have sufficient practical experience in real classrooms as a part of their initial education, it is not surprising that initial teacher education courses are demanding in order to ensure that teachers are encouraged and supported throughout their careers to review their learning needs and to acquire new knowledge and skills, as concluded the Council on Improving the Quality of Teacher Education (CEU, 2009). Propositional and procedural knowledge related to the politics of sustainable development and citizenship should be a core component of the type of professional learning, and this should involve and encourage closer links between the ESD and citizenship education communities (Huckle, 2009). Hence, it is of essence to have a strong learning community which requires all stakeholders to actively participate in sharing common values, beliefs, and knowledge in order to pass on their wisdom from generation to generation and embracing a strong sense of loyalty and belonging among themselves, so as to achieve together both individual needs and shared missions of the community (Rungrojngarmcharoen, 2013).

The overall training purpose of the adult education projects derives from the needs of analysis of the reference group and the relevant stakeholders, determines the importance of the project and defines its range. According to the Greek Law 1982/90 article 11p.13, the purpose of the $\mathrm{EE}$ is to make students realize the relationship between humans and natural social environments, be aware of the problems associated with, and involve them in specific projects that contribute to the general tackling effort. In order, teachers of primary and secondary schools to fulfil these objectives, need proper and adequate education and training. Telling teachers what to do and how to change has proven to limited effects on changed practice, so, it is necessary to give teachers a feeling of ownership of the process of the change they are going through (Smith, 2011). A thrust of ESD is reorienting education projects to address sustainability by weaving knowledge, skills, perspectives, values and issues related to sustainability into existing curriculum and educational projects (UNESCO, 1997; Mckeown, 2012). Reorienting teachers' education is important to ensure that sustainability is taught as part of a primary and secondary education.

The criteria that take into account the analysis of the objectives of a training or adult-education project listed in the following way: participation of the trainees in formulation of the project objectives, assignment of project objectives to the educational 
needs of the target population, appropriateness of the educational goals to meet the needs of the target population, realism in achieving the objectives, setting objectives based on the knowledge and skills to be acquired, setting objectives on the basis of the socio-political and cultural environment that the new knowledge and skills will be used. In particular, those project that designed and implemented in the frame of the EE, must also meet the goals, objectives, principles and characteristics of the EE, such as those raised in the Belgrade Conference in 1975 and the conference in Tbilisi in 1977, as analyzed by the UNESCO and others (UNESC, 2004; UNECE, 2005; Flogaiti E., 1993\&2006; MNTUoA, 2007).

\subsection{Description of the project content}

The framework of the post-Lisbon strategy should address the following four strategic objectives: making lifelong learning and mobility a reality; improving the quality and efficiency of education and training; promoting equity, social cohesion and active citizenship; enhancing creativity and innovation, including entrepreneurship, at all levels of education and training (CEU, 2009). Ojedokun (2012) is wondering how ESD can be diffused into teacher education project in Nigeria, since teachers in the (primary and secondary) school only need to implement the curriculum (teach); as it is not their responsibility to design it: more importantly because they have too many objects (teaching, assessment, report writing etc) to cope with (McKeown, 2012). Hence, in order to properly serve teacher education departments as advocates of ESD, answers have to be provided to questions such as, what should the content of ESD be, what methods/strategies should be theorised about and expatiate upon, how could ESD be introduced into the school subjects' curriculum. If the right answers are derived, pre-service teachers could be adequately prepared and well equipped to become further advocates of the subject matter of ESD. As the evolution of EE towards ESD occurs internationally, at a rapid pace during the last decade, and as it is a strategic priority of the current Decade of UN-DESD: United Nations Decade of Education for Sustainable Development 2005-2014 (UNECE, 2005), the specialists of ESD expressed the view that the ESD programs should be focused on promoting justice and human values in non-violence and respect for life (Hesselink, Kempen, and Wals, 2000). Each local problem is recognized as a part of the global that raises ethical issues of interdependence and shared responsibility in relation to social and environmental justice (Scott, 2007).

The criteria for the structuring of the project evaluate the classification of the project content (matter distribution into sections, separation of theoretical training and exercise), the levels of the construction according to the knowledge of the trainees, the level of skills and competencies development with the practical exercise, the level of changing attitudes, values and behaviour in order to improve the communication capacity and collaborative ability of the trainees, the temporal sequence and rhythm of the project (total duration, duration of the theoretical training and practice), also the fullness and clarity of the project proposal.

\subsection{Selection of pedagogical and teaching methods, techniques and educational resources}

Crucial importance in the choice of the methods in adult education plays the general characteristics that make up the degree of adultness of the trainees. The maturity, the sense of 
perspective and self-determination, with attendant rights and responsibilities that individuals show up, have been taken into consideration by trainers in order to identify and choose the strategic methodology that will be followed in an educational/training project (Kokkos, 1999). In the last nationwide survey of the Greek Pedagogical Institute (MPE, 2010) for the training needs of teachers, on the most efficient form of training, most comments are referred to the methodology of distance education and the use of new technologies combined with face to face teaching (mixed system) in accelerated courses with modern teaching methodologies.

3.4.1 Self-directed learning. Classrooms now contain a more heterogeneous mix of young people from different backgrounds and with different levels of ability and disability. Consequently, teachers are required to use the opportunities offered by new technologies to respond to the demand for individualised learning and manage tasks consequent upon increased school autonomy (CEC, 2007). The trainer, as learning facilitator, sets to learners the goal, leads and continually assesses their progress during the learning process, guides the groups with the notion of coordination of the procedures in order to achieve the goal (Rogers, 1989). The trainer encourages the efforts of learning and support the learners with the demanded material, motivation and feedback (Kokkos and Lionarakis, 1999).

3.4.2 Inter/multi-disciplinary approach of the issues. Adult education and environmental education promote the interdisciplinary, multidisciplinary, holistic approach of the objects of the projects. Student teachers learn not only through interactions with mentor teachers, university faculty, administration, parents and the community, but also from interactions with each other and through introspection and reflection (Kang \& Nickel, 2012).

3.4.3 Development of the critical capacity of trainees. The most important element in a training project, from the aspect of methodology, is to promote the process of learning and develop the ability of meta-cognition. Of high importance is also the awareness of the mechanisms of creation, termination and evaluation of a problem. The teachers' training in the EE should include the necessary scientific and technological knowledge, to enable a full understanding of the causes and impact of environmental problems as well as to evaluate the proposed solutions (UNESCO, 1997).

\subsubsection{Innovative elements of the project}

Smart, sustainable and inclusive growth are the three priorities of the European Strategy "Europe 2020". As for the smart growth, it can be achieved by developing an economy based on knowledge and innovation (EC, 2010). The strategic applied methodologies in adult education are supported by the computer learning, distance education, group cooperation learning and experiential learning. Main educational techniques are lecture, discussions, seminars, working groups, organization and implementation of action plans (projects). Since each training technique has its advantages and disadvantages, it is necessary for each trainer to select and combine the most appropriate and effectively teaching objectives.

3.4.5 Ensuring the active involvement of trainees. In the current trends in didactics of adults and minors prevails the active model of learning, in which learners design by themselves 
their own process of learning and try to interpret it through their experiences. Projects shall be evaluated in the following: developing a sense of participation-awareness-alert in problem solving of the trainees, promotion of active involvement of the participants in all phases of the decision making, work with group-cooperative spirit and securing conditions in pedagogical and didactic level, foundation of lifelong learning, use of ICTs, libraries et al in teaching and learning, undertaking initiatives to addressed issues (self-motivated).

3.4.6 Analysis of local/topical /personal interest of learners' issues. In a training project of environmental education is evaluated the exploitation of the project results in a personal/local/national level, the emergence of personal experiences, the engagement of the local community, the global dimension of local issues.

3.4.7-11 Evaluation of the project. The evaluation of the training project is a research process of collection, processing, analysis and interpretation of data of the thematic areas of the project, carried out systematically, as applied research. The proper choice of method and techniques that will be used in the evaluation are a key factor for the reliability of its results. These experimental and psychological processing methods utilize transaction, cooperation, communication, comparison, correlation, follow-up, review, case study, projects, compliance and study records, discretion, content analysis, self-analysis, data analysis, and usually, are used combinations of methods (Dimitropoulos, 1999). The European Commission is developing a statistical indicator on the professional development of teachers and trainers. For the trainers, assessment and evaluation activities comprise in administering diagnostic skills tests for assessing learning achievements of learners (in cooperation with colleagues and in-company trainers), monitoring in-company trainers, giving feedback to support the educated learning and professional development of trainers. On the other hand, in order trainers to successfully carry out the activities, they need to know assessment theories, techniques and tools, to have a global understanding of training and relation to work-based training, and have interpersonal skills (Volmari et al, 2009). Wong \& Yeung (2003) asked six items the teachers participated in a training program about their perceptions of the various aspects of program delivery. Teachers responded on a Likert-type scale about the achievement of the course objectives, usefulness of the projects to professional needs, length of course/service, instructor's preparation of information, interaction between instructor and course participants, learning materials used or provided. The degree of satisfaction in the considered factors is related to the degree the individual believes his/her success criteria have been met, especially if the individual places great importance on these criteria which include pay, respect, personal growth and family life balance (Adu et al, 2012).

\subsection{Determination of requirements for the implementation of the project}

The Council of the European Union Conclusions on the strategic framework for European cooperation in education and training, made some suggestions in order to achieve the strategic objective 2 of "ET 2020" of Improving the Quality and Efficiency of Education and Training (CEU, 2009). It is, among else, important to improve the governance and leadership of education and training institutions because high quality will only be achieved through the efficient and sustainable use of resources - both public and private, as appropriate - and 
through the promotion of evidence-based policy and practice in education and training.

At this stage of the program design, becomes essential a negotiation between training needs and availability of learners and resources. Smith (2011) sets the question if those who are to guide and support professional development in schools hold the essential knowledge and competence themselves.

The determination of requirements for the implementation of the project includes the estimation for places, equipment, required time, administrative support, knowledge sources, use appropriate trainers, competent public services, the national statistics office, specialized literature from the internet, magazines, books, records, interviews) and specialists (EKDDA, 2013). The general index infrastructure provision consists of the sub-indexes halls, teaching aids, brightness, sound insulation and room setup, cleanliness, air conditioning-heating, disabled access. The selection and construction of the content of the project referred on the chronological sequence and rhythm, the duration, the distribution of matter in sections throughout theoretical training and practice making.

The evaluation criteria of full record of the requirements of a training project, are regarded to the preparation of the budget required to purchase additional equipment, expenditure required for fees, availability of trainees, the explored required space, adequacy, quality, usability, type of use and suitability, the required equipment, available PCs, internet access, access to libraries, adequacy, quality, usability, ensuring the necessary scientific and administrative support, qualified teaching staff (training, experience), utilization of external collaborators, listed of the sources of knowledge, if providing access to sources of knowledge, availability of educational and scientific staff, previous experience in designing and implementing educational project, estimated the required duration by realism.

\subsection{Prediction of mechanisms for dissemination of the project results}

As for the prediction of mechanisms for dissemination of the project results, 8 criteria are listed below evaluating 3 research questions of prediction for feedback, determination of the desired results and clarification of the ultimate beneficiaries, by invitation to the local and educational agencies and those related to the subject. Feedback is promoted by organization of workshops, open discussions, production and distribution of material produced for the needs of the project, improvement of the project itself and any repetition by using the findings of the evaluation. In each project design needs to become provision of the mode for detection of the results, of the satisfaction with the expectations of the target group, of the satisfaction of the proposals and choices of trainees, if the project meets of social requirements. The trainer improves himself, also, within the training project with the continuous upgrading of teaching skills and the development of his personality. At current levels of unsustainable practice and over consumption it could be concluded that education is part of the problem. If education is the solution then it requires a deeper critique and a broader vision for the future. Thus, the whole educational systems redesign needs to be considered to challenge existing frameworks and shift our thinking beyond current practice and toward a sustainable future (UNESCO, 2005). 


\section{Epilogue}

Teachers, in order to successfully meet the needs of teaching the subjects of EE, need to take specialized knowledge in theoretical training and practice by specially designed Adult Education (AE) project (Kapsalis \& Papastamatis, 2000; EC, 2010). With EE, they can achieve improvement of ecological knowledge, attitudes, skills and behaviours towards management options and development of the state and local communities (UNESC, 2004). It presupposes, searching and cultivating of our stem ethical values and respect for aesthetics, economy and life in general. Environmental EE is carried out in a team level. Leverages existing training methods, also forms new in order to be constantly up to date and effective. Complementing the subjects taught in schools, provide excellent potential involvement of students and teachers in crucial environmental issues which humanity is facing today more than ever. Sustainability has become a more common term in daily life. To be effective, teachers must be conversant in contemporary themes and topics (Mckeown, 2012). There is an urgent need to re-examine the nature and structure of schooling in a more critical way to address ESD in its broadest context, i.e., school organizational principles, operational practices, school grounds management, and curriculum content (UNESCO, 2005) as a "meta-framework" used to assess environmental literacy in different places and with different populations (Paden, 2012). The hope, for the sake of future generations, is to help invoke the courage we all need to face down a curriculum-constrained education system in a climate-constrained world (Johnston, 2009). Let this be our transformative gift, our way of showing our love as teachers, to all of the children, for all time. As Confucius said, every truth has four corners: as a teacher, I give you one corner, and it is for you to find the other three.

\section{References}

ADA. (2013). Training Programs of the Greek Training Institute, Schedule of January-July

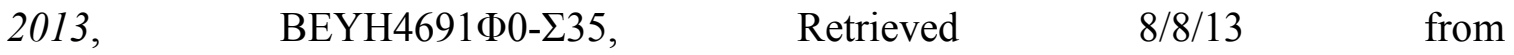
http://www.ekdd.gr/ekdda/images/seminaria/egkiklios_A_2013.pdf

Adu, O.E, Titilola O., \& Eze R. I. (2012). Career Advancement, School Relations and Support Service Factors as Determinant of Teacher Productivity in Public Secondary Schools in Oyo State, Nigeria. International Journal of Education, 4(4).

Bell, J. (1997). Methodological design of Pedagogic and social Research. Gutenberg Publications: Athens.

CEC. (2007). Commission of the European Communities. Improving the Quality of Teacher Education. Communication from the Commission to the Council and the European Parliament Com (2007) 392, \{Sec (2007) 931, Brussels, 3.8.2007.

CEU. (2009). Council of the European Union (2009) Council Conclusions on a strategic framework for European cooperation in education and training ("ET 2020") 2941th Education. Youth And Culture Council meeting, Brussels, 12 May. 
Cohen, L., \& Manion, L. (1994). Research Methods in Education (4th ed.). London: Routledge.

Dimitriou, A. (2007). Evaluation of School Environmental Programs, University Notes of the Post Graduated Program of Environmental Education, Aegean University, Rhodes, Greece.

Dimitropoulos, E. (1999). Evaluation of the Education and the Educational Output. Grigoris Publications, Athens.

EC. (2010). Europe 2020: A strategy for smart, sustainable and inclusive growth. Retrieved $9 / 8 / 13$ from http://ec.europa.eu/eu2020/pdf/COMPLET\%20EN\%20BARROSO $\% 20 \% 20 \% 20007 \% 20$ -\%20Europe\%202020\%20-\%20EN\%20version.pdf

EKDDA. (2013). Indicators for the evaluation of programs of the Greek Training Institute, Retrieved 8/8/13 from http://www.ekdd.gr/ekdda/index.php/gr/2012-06-19-08-31-50/48-2012-06-29-12-10-45/1 18-2013-01-04-09-27-47

MNTUoA. (2007). Training material for the Seminar of Teachers and Education Officials on Environmental Education, EPEAEKII, Writing Team with coordinator Koutsopoulos K., National Technical University of Athens

Flogaiti, E. (1993). Environmental Education. Greek University Publications

Flogaiti, E. (2006). Education for the Environment and the Sustainability. (2 ${ }^{\text {nd }}$ ed.). Greek Letters Publications.

Frangoulis, I. (2006). Design and development of quality indicators for the evaluation of local history programs in Primary Education, $5^{\text {th }}$ Panellenic Congress of the Greek Pedagogic Company, Thessaloniki 24-26 November.

Hesselink, F., Kempen, P., \& Wals, A. (Editors). (2000). ESDebate: International debate on education for sustainable development, Commission on Education and Communication of IUCN - The World Conservation Union, IUCN Publications Services Unit, Switzerland.

Huckle, J. (2009). Consulting the UK ESD community on an ESD indicator to recommend to Government: an insight into the micro-politics of ESD, Published in Environmental Education Research, 15/1, February 2009, pp.1-16, available on $6^{\text {th }}$ January 2013 at http://john.huckle.org.uk/download/2937/EER2009.doc

Iosifidis, T. (2003). Analysis of Qualitative data in Social Sciences. Kritiki Publications: Athens.

Johnston, J. (2009). Transformative Environmental Education: Stepping Outside the Curriculum Box. Canadian Journal of Environmental Education, 14(1), 149-157.

Kang, H-W., \& Nickel, M. (2012). Many pieces of the puzzle: a collaborative process of 
becoming a teacher, Journal of Case Studies in Education. Retrieved 17/8/13 from http://www.aabri.com/manuscripts/11885.pdf

Kapsalis, A. \& Papastamatis, A. (2000). Adult Education, vol B, Adult Teaching, University publications, University of Macedonia, Department of Educational and Social Policy, Thessaloniki.

Kastani, K. (2005). Presentation of a methodological instrument for the Content Analysis of Environmental Projects, $1^{\text {st }}$ Congress of School Environmental Programs, Korinthia 23-25 September.

Kokkos, A. (2008). Adult Education in Europe and Greece: Determination of the scope, trends, $\quad$ policies. $\quad$ Retrieved 12/12/2007 from http://class.eap.gr/QuickPlace/ekp64/PageLibrary

Kokkos, A. \& Lionarakis A. (1999). Open and Distance Education-Relations of educators and learners, vol B, Greek Open University, Patras.

Mckeown, R. (2011). Using Rubrics to Assess Student Knowledge Related to Sustainability: A Practitioner's View, Journal of Education for Sustainable Development 2011 5: 61, available on 7th January 2013 at http://jsd.sagepub.com/content/5/1/61

Mckeown, R. (2012). Teacher Education 1992 and 2012: Reflecting on 20 Years. Journal of Education for Sustainable Development, 6(1), 37-41.

MPE. (2010). Contribution of investigative training needs in teacher education: Comparative Results, "Major Program of Teacher Training". Retrieved 10/8/13 from http://www.epimorfosi.edu.gr/images/stories/e-books/ap_anagk/pdf/8_sysxetisi.pdf

Ojedokun, O. (2012). Diffusing Education for Sustainability into Teacher Education Programme in Nigeria: A Theory in Use. World Journal of Education, 2(2).

Paden, M. (2012). NAAEE Releases Framework for Assessing Environmental Literacy: Being Used in 2015 OECD Assessment. Journal of Education for Sustainable Development, 6, 17. http://dx.doi.org/10.1177/097340821100600107

Rogers, J. (1989). Adults learning (3rd ed.). Open University Press,

Rungrojngarmcharoen, K. (2013). A Theoretical Synthesis of Knowledge Sharing and Educational Leadership for Sustaining Learning Communities. US-China Education Review A, 3(2), 133-139.

Scott W. (2007). Goodfellow M. and Andrew-Power K. (editors), Raising standards: making sense of the sustainable schools agenda, Specialist Schools and Academies Trust, London.

Skordoulis, K., \& Sotirakou, M. (2005). Environment: Science and Education. Leader Books, Athens.

Smith, K. (2011). Professional development of teachers-A prerequisite for AfL to be 
successfully implemented in the classroom. Studies in Educational Evaluation, 37(1), $55-61$.

Sofoules, K. (2005). The Environmental Policy from the standpoint of the instructor of Environmental Education, in Kaila M. "Environmental Education: Research Data \& Educational Design”, Atrapos Publications, Athens.

UNECE. (2005). UNECE Strategy of the Education for the Sustainable Development, Vilnius, 17-18 March 2005.

UNESC, (2004). Draft UNECE Strategy for Education for Sustainable Development, Addendum, Background, 2nd Regional Meeting on Education for Sustainable Development, Rome, 15-16 July 2004, cep/ac.13/2004/8/add.1, 18May 2004, Economic Commission for Europe Committee on Environmental Policy

UNESCO. (1997). Declaration of Thessaloniki, University of Athens, MIO-ECSDE, Thessaloniki.

Vergidis, D. (1999). Design and structure of adult education programs, in Adult Education, vol $C$, Greek Open University.

Volmari, K., Helakorpi, S., \& Frimodt, R. (2009). Competence Framework for Vet Professions, Handbook for practitioners, Finnish National Board of Education and Editors, ISBN 978-952-13-4118-2 (pdf), Vammalan Kirjapaino Oy, Sastamala

Wong, E., \& Yeung, A. (2003). Evaluation of teacher development programs: participant satisfaction and recommendation. Studies in Educational Evaluation 29, 57-66. http://dx.doi.org/10.1016/S0191-491X(03)90005-8

Zigouri, E. (2005). Evaluation of Environmental Education Programs-Theory and Praxis. Publishing by Tipothito.

\section{Copyright Disclaimer}

Copyright for this article is retained by the author(s), with first publication rights granted to the journal.

This is an open-access article distributed under the terms and conditions of the Creative Commons Attribution license (http://creativecommons.org/licenses/by/3.0/). 